\title{
AS DOENÇAS CUTÂNEAS NAS TERMAS DO LUSO (1856-1858)
}

\section{CUTANEOUS DISEASES IN "TERMAS DO LUSO" (1856-1858)}

\author{
A. Poiares Baptista \\ Professor Catedrático de Dermatologia, Jubilado, Faculdade de Medicina de Coimbra / Retired Professor of \\ Dermatology and Venereology of the Coimbra University, Portugal
}

Por decisão do autor, este artigo não foi redigido de acordo com os termos do novo Acordo Ortográfico.

Recebido/Received - Fevereiro/February 2012; Aceite/Accepted - Maio/May 2012

Por mero acaso tivemos a oportunidade de tomar conhecimento de um pequeno livro "Notícia dos Banhos de Luso - Apontamentos sobre a história, melhoramentos, e administração d'estes banhos", publicado em 1859, pela Imprensa da Universidade de Coimbra, redigido por António Augusto da Costa Simões. O seu autor é uma das figuras mais relevantes na história da Medicina portuguesa: como professor da Faculdade de Medicina, baseado nos ensinamentos obtidos em duas longas viagens de estudo aos principais centros médicos europeus, foi o introdutor do ensino médico experimental, renovador dos laboratórios das cadeiras básicas e das análises químicas, do ensino da fisiologia e da histologia, promotor da renovação das instalações do hospital universitário, etc. Foi também, embora por curtos anos, reitor da Universidade, presidente da Câmara Municipal (a ele de deve a implementação da água canalizada na cidade e a renovação dos actuais cemitérios) e membro parlamentar. $\mathrm{Na}$ realidade, podemos afirmar que viveu exclusivamente para a Faculdade, para a Universidade, para Coimbra e para a sua terra natal.

Natural da Mealhada (1819-1903), desde sempre se interessou pela região e naturalmente pelas águas do Luso, conhecidas de longa data como "Banhos", com virtudes terapêuticas, mas com instalações muito rudimentares. Graças à sua iniciativa, os "Banhos de Luso" foram transformados na instância termal hoje bem conhecida, inaugurada em Junho de 1856 e constituída então por um edifício próprio com 18 banheiras equipadas com água quente.

$\mathrm{Na}$ "Noticia" são publicadas as "estatísticas médicas" dos anos 1856, 1857 e 1858 referentes a um total de 5464 "banhistas". Numerosa é a patologia anotada, nomeadamente as "molestias da pelle" o que despertou a nossa curiosidade. Conforme está expresso no relatório, "O autor da estatística médica do estabelecimento de Luso, seguiu a classificação do Ensaio Dermosographico do Sr. Bernardino António Gomes, na designação das molestias cutâneas; e, nas outras moléstias, adoptou a classificação do actual compêndio da pathologia interna da Universidade". Compilando os diagnósticos dermatológicos verificamos que estes são muito diversos. Estão mencionadas papulas, fogagem, coceira, escamas, lepra, psoriase ou erupção psorica, ichtyose ou pelle de peixe, caspa, maculas, ephelides, bortoeja, purpura ou tabardilho, erythema, erysipela chronica, bolhas, rupia, herpes, miliaria, pustulas, empigens, ozagre, tinha, sarna, elephantiase dos gregos, elephantiase dos árabes, ragadas anonimae ou psoriase palmaria, pityriase, carepa vermelha, morphea, sycose ou figos, tuberculos, sarabulhos ou gotarrozada".

A nomenclatura mencionada é realmente a usada por Bernardino António Gomes no "Ensaio dermosographico" mas julgamos que a sua maioria são de expressão popular, pois estão escritos como sinónimos. Assim, temos como exemplos: a "fogagem", incluída na ordem "Papulae" é designada por "Lichen": "papulas rubras, pruriginosas, precedidas commumente de febre, d'ordinário em adultos, repetentes, e não contagiosas", havendo 8 variedades (fog. simples, fog dos cabelos, fog. circunscrita,...); o "ozagre", incluido na ordem "Pustulae", é a "crosta láctea" ou "porrigo larvalis" (Willan e Bateman) ou "teigne muqueuse" (Alibert); a "carepa vermelha", da ordem das "Esquamae" ou "enfermidades escamosas" é uma variedade da "pityriase": "malhas pruriginosas, de princípio vermelhas e ásperas, em breve furfuraceas e como alvacentas. 


\section{História da Dermatologia}

Situação no corpo das pessoas idosas"; o "sarabulho ou gottarrozada" deve ser o actual acne juvenil, com as variedades de "gottarrozada simples ou espinhas carnaes" e de "gottarrozada ou sarabulhos steatomatosos"; a "rupia", incluída na ordem das "vesiculas", é descrita como "vesículas amplas, achatadas, distantes, pouco inflamadas á roda da base, vagarosas em seu progresso, seguidas de úlceras saniosas, com crostas mui caducas e de mui prompta regeneração", havendo "rupias simples", "proeminentes" e "corrosivas"; na "morphea" está apenas indicada a "morphea branca" (esclerodermia em placas?) também designada por "vitiligo leuce, e alphos. Amat.Lusit."; o "tabardilho" é sinonimo de "purpura" : "manchas ordinariamente da cor e feição de mordeduras de pulga sem ponto central, não prominentes, nem sumidiças pela pressão (pintas), ás vezes muito maiores, de diversas feições e roxas (livores), dispersas por toda a pelle. Duração de 1 a 5 semanas, raras vezes maior", havendo as variedades "apyretico", "hemorrágico", "ortigoso", "senil", "contagioso" e "terção". É bem evidente que baseados nas descrições clínicas e nas designações, não nos permitem, na grande maioria dos casos, formular um diagnóstico actual.

Quanto à sua frequência há a destacar, nos 3 anos indicados, o grande numero de "herpes" e de "empingens", superior a todas as restantes doenças (em 1856, somaram 481 em 1057 banhistas), seguidas pela "fogagem", "coceira", "ephelides" e "elephantiase dos gregos", "rheumatismo articular chronico", "hemorrhoidas" e "úlceras". Verificamos assim que as doenças cutâneas eram as que mais motivavam os doentes a recorrer aos "banhos". Anotemos ainda que 304 pessoas tinham ido às termas para "tomar banhos com fins hygienicos"...

Sobre o "resultado da moléstia depois dos banhos" estão assinalados, no conjunto, muito poucas curas, numerosas melhorias e mesmo estado, e grande número de "resultado desconhecido". No que respeita às dermatoses as melhorias predominam nas "fogagens", "coceira", "herpes" e "empingens".

É muito curiosa também uma exposição, cujo teor julgamos muito fantasioso, apresentada ao Prof. Costa Simões, em 12 de Outubro de1846", por "Agostinho Dias da Graça, aprovado em cirurgia e medicina practica, membro correspondente da Sociedade de Sciencias Médicas de Lisboa, académico honorário da Real Academia de Sciencias de Cadiz". Nela está escrito: "10 - Há mais de vinte anos que eu tenho mandado para os banhos de Luso, doentes com moléstias de pelle, que tinham resistido a todos os remédios mais enérgicos que a arte tem recomendado; e foram dos dictos banhos perfeitamente curados, sem que até agora tenham recaído. $2^{\circ}$ - Os mesmos elephantiacos, os leprosos, os boubaticos e os atacados já de morphea, sendo no principio d'estas moléstias, se curaram radicalmente com o uso dos dictos banhos; e estando já com úlceras, torpor e adormecimento de pés e mãos, e não podendo suster o calçado, nem mover os dedos das mãos, com o uso de repetidos banhos de Luso tem adquirido tantas melhoras, que a maior parte das chagas se têm curado, outras melhorado; desapparecendo o torpor, e a"herpespparecendo a sensibilidade e o movimento; e talvez se tivessem também curado radicalmente, se naquelle logar houvesse um professor perito e zeloso, que désse aos doentes um methodo curativo e dieta competente, na forma dos estatutos que ousadamente tomo a liberdade de offerecer a V. S. ${ }^{\text {q, }}$ e então que gosto, que prazer, e que galardão não seria para V.S. $\stackrel{a}{\text { e }}$ que dicta não seria para os portugueses, se nós tivessemos a felicidade de termos em Portugal um remédio, que curasse os lázaros! Seríamos envejados pelos estrangeiros; e elles mesmo viriam aqui curar as suas moléstias, e trazer-nos os seus cabedaes." Na continuação, critica o funcionamento dos banhos e propõe-se enviar um regulamento mais pormenorizado que o Prof. Costa Simões informa não ter recebido "nem os trabalhos prometidos sobre o effeito das águas de Luso" embora acrescente, talvez ironicamente, que ainda não tinha "perdido a esperança de os obter, e que devem ser de importância por terem sido colhidos por um clínico hábil e durante uma observação de muitos annos".

Hoje, é sabido que as bem conhecidas e as bem equipadas Termas da Água do Luso tem particular indicação nas doenças renais, hipertensão arterial, afecções respiratórias crónicas e reumatismais. Os que padecem de "maleitas da pelle" deixaram de constituir a principal clientela e "os banhos com fins hygienicos" deixaram de ser um motivo, a menos que consideremos o SPA termal como o seu moderno substituto... 